\title{
Localized Urothelial Carcinoma of the Renal Pelvis and Ureter
}

National Cancer Institute

\section{Source}

National Cancer Institute. Localized Urothelial Carcinoma of the Renal Pelvis and Ureter. NCl Thesaurus. Code C8167.

A transitional cell carcinoma of the renal pelvis or ureter confined to the area of its original growth. 